\title{
Lexical Impact for the Ideology in Headline News: Indonesia Salt Import Issue
}

\author{
Aniesa Haque Ayu', Nurul Chojimah², Esti Junining ${ }^{2}$ \\ 1, Linguistic Graduate Program, Faculty of Cultural Studies, \\ Universitas Brawijaya, Malang, Indonesia \\ ${ }^{2}$ Lecturer Linguistic Graduate Program, Faculty of Cultural Studies, \\ Universitas Brawijaya, Malang, Indonesia
}

\begin{tabular}{l} 
Article Info \\
\hline Article history: \\
Submitted Des 22, 2019 \\
Revised Feb 16, 2020 \\
Accepted August 29, 2020 \\
Published Nov 2, 2020 \\
\hline Keywords: \\
Ideology \\
Headline news \\
Critical Discourse Analysis \\
News
\end{tabular}

Article Info

Submitted Des 22, 2019

Revised Feb 16, 2020

Accepted August 29, 2020

Published Nov 2, 2020

Keywords:

News

\begin{abstract}
This research focused on how the ideology revealed from the headline news that focus on its lexical choice that hide the meaning. This study used an online media news that published on Detik.com that has the headline Punya Garis Pantai Terpanjang di Dunia, Kok RI Impor Garam? As the mind object. This object also focused on its discourse as the mind media of analysis and the headline used as the point of view through the news. To analyse the object the researcher used critical discourse analysis by Van Dijk as the mind approach in analysing the discourse through the news and supported in metafunction by Halliday which concern on ideological metafunction to help revealing the ideology. The study used qualitative as the design of analysis, it needed to describe the data. The aim of doing the research was to come up the ideology that hidden behind the headline of news. The issue was controversially and it would be the grand topic to be analysed. From the analysis known that the discourse of the news could build contradictive perspective between the headlines through the whole of discourse. That perspective came from the discourse which has been selected in its lexical and composing the pattern of sentences.
\end{abstract}

\section{Corresponding Author:}

Aniesa Haque Ayu,

Linguistic Graduate Program Department, Faculty of Cultural Studies,

Universitas Brawijaya

Jl. Veteran, Malang, Indonesia.

Email: aniesahaqayu9@gmail.com

\section{INTRODUCTION}

Indonesia known as its various kind of abundant natural resources, all the material exist because it located in geographical areas with fertile soil. All the plants growing well such as vegetables, herbs and spices, and tubers. This country surrounded by the ocean that called as maritime country that make Indonesia can be source of producing salt. However, the fact does not as its expectation. In the last of 2018 up to June 2019 some news reported that Indonesia did importing salt. In some reason, Indonesia was high rainfall that caused drying in salt ponds is inhibited. That such an irony when the country that has the longest coastline did the importing salt. This topic would be the grand issue for this study. Detik finance, one of media online which reported this topic serve the ideology to open the reader mind in concluding the situation. Because, every media has its power to compose the text for making a discourse to be a news. According to Van Dijk 1998 which cited in He and Zhou 2015 argue that ideology such a system which start from the idea and believe which evolve from the member social group or organization which interest in societal issue. This study depend on the news text of Detik finance.com as the main object which serve the topic. 
Detik finance is an online media newspaper that can be accessed in www.detik.com or can be downloaded its apps. This media is available in several news topic such as finance, economical, health, political, lifestyle and other. Detik.com is one of the popular site of news in Indonesia which owned by Chairul Tanjung and cooperated by Trans Media which launched in July 1998. The media would be updating its breaking news for making the newest topic as its characteristics. Media absolutely has its power to create a news which has an ideology, in fact every news contained a discourse which reveal the ideology. As Metila (2013) that was cited in Isti'anah 2016 assume that headline present what news report assure from the media as the crucial information. That the reason of the media does not be neutral. Discourse not only around the text but also talk or the utterance that use for reveal the meaning or opinion and perspective from the reader or hearer. However, media are in power to make a discourse to lead the reader in one perspective.

Beside of CDA as the main approach, this study also use another approach to help revealing the ideology, another one is lexical choice approach which would analyse in contain of grammatical and structure use. As Halliday's theory in 1994 vocabulary is a major determine of idea in making structure of utterances, he also argue that lexical classification is the basic of cognition in human being. Because every body of human being has their own social culture that make their own representation linguistic in every case. Halliday's theory also has a form in systematic functional grammar that refer to the metafunction that divided into three, there are ideational function, interpersonal function, and textual function. This study only focus on the ideational function which need to reveal the ideology.

In Halliday's systemic functional grammar he states there are tree function of linguistically discourse function. For the focus of this study the researcher only use ideational function to conclude the ideology. For this function Halliday divided into two categories, experiential and logical metafunction. Experiential metafunction organize our understanding of the view world that can be known from looking at grammatical use in representation clause and logical metafunction which refers to find the meaning among the clauses.

For this case of the study the writer refer to several previous study which has close relation for this study. The article that written by Arina Istianah, 2018 which entitled Rohingya in Media: Critical Discourse Analysis of Myanmar and Bangladesh Newspaper Headlines discuss about the headline news which contained of the ideology. This two articles revealing the ideology between two papers which use the same case as the topic. This article also analysed in both textual structure for each headline by using Halliday's system functional grammar. The result of the study the researcher concluded a different perception between two headline newspaper that reveal the ideology, first that Myanmar newspaper headline cover the issue by blowing up the good deeds by Myanmar government and Bangladesh newspaper headline show the action that done by the Rohingya to save themselves.

Another study that strengthen this article taken from the study article by Anggara Jatu Kusumawati which has the title A Discourse Analysis of SBY's International Speech Text: A study on Critical Linguistics. This article discuss about the international speech of SBY as the Indonesian president in verbal discourse which analyse in CDA and SFL approach by Halliday. While during the analysing the data the author use grammar based on choice of word, clause arrangement and figure of speech to expose the meaning that has purpose to the listener. This study analysed the using lexical choice and word choice and it verbal message which has packaged for building the ideology for the international listener. 
Moreover, the study also refers to the study of Nuning Yudhi Prasetyani at all that entitled Translation Analysis on Idiological Lexicon Choice in how to win friendsand influence people book and its Indonesian translation. This reference study focus on the translation pattern from source novel to the target language in Indonesia language that need to catch up the ideology behind the translation version. This study also used theory of Van Dijk in Critical Discourse Analysis that focus on socio-cognitive concept through society, cognition and discourse in triangulation framework. The finding of this study compose that there are an ideology from the author of source language which can be catched by the transtlator in target language until it become a one way in persception although presented in different language. From that statement lexical choice, take a role in composing the text.

Another way that researcher used for strengthen the study it refered to the study by Xianzhong He and Zulu Zhou that the study entitled Contrastive Analysis of Lexical Choice and Idiologies in News Reporting the same Accidents between Chinese and American Newspaper. This study analyse the ideology of the same accident that has reported by two different media in the website of China Daily and The Washing Post. In his study the researcher focuse on analysing the data by lexical choice which concern in different of word choice and verbal message. For that method, the researcher got the finding that the objective of the news is not neutral as seem from the ideology that used for influence for the readers and this study seemingly impersonal.

However, this study do relate by the media which use the ideology serving the news, it absolutely contributed the CDA as the mind paradigm for analysing the data. Therefore, the study by Yanto and Elfi Mariatul Mahmudah, which has the study entitled The Strategy in Newspaper Text (A Critical Discourse Analysis of Newspaper Text), has big contribution with this study. This study claim that news could be a reference or source that use for interpreting public problem, than it used the strategy before reporting. This study conclude that the news consist of the word choice, the uterances, and local coherence that used to compose the text of news until revealing the fact from the news and objectivity that could be accepted by the reader.

This study only focus in revealing the idiology of the news media that used Halliday's theory in systemic functional linguistics that focus on ideological function and CDA as the mind paradigm for the whole of analysing. According to the Van Dijk ideology as a science of ideas, that refer to the way of media in composing the news by selecting the word and utterances to make sure that the news is appropriate as the media want. From this concept seem that every media has it own power to combine the ideology in every news topic. Other way the reason of using SFL or systemic functional grammar to get the interpretation of the language as it use, because SFL claim that language as a social process not only neurological concept.

Therefore, with the headline the component of the utterances that make a discourse contained the hidden meaning will create some ideology. The aim of this study the researcher want to reveal the ideology of the headline news to prove what the author of media aimed in serving the news. Furthermore, this study have some significant problem to make the aim clear it conclude as two research question: (1) how do lexical choice control the news as public discourse? (2) What is the ideology that hidden behind the headlines? 


\section{THEORY AND METHODS}

Another way to get the valid research the researcher use the CDA as the approach for analysing the text which focus on lexical choice as the sword for peeling the word that use in news. For the focus of the theory the researcher concern on its lexical pattern of the clause. This approach would help the analysing in catching the ideology of the headline. For the approach the researcher would depend on the theory of Van Dijck (1995) in CDA which say that CDA is a special approach in discourse analysis, which focuses on discursive conditions, components, and consequences of power abuse by dominant (elite) groups and institutions. It examines, as Van Dijk argued, patterns of access and control over contexts, genres, text and talk, their properties, as well as the discursive strategies of mind control (Ulinuha et al, 2013). For this study CDA according to Van Dijk, (1997) is not kind of discourse which found only in the formal grammar and contain of structure in utterances, but CDA is a discourse which are available in real social situation between interaction and communication. In the discourse, not only the sentence or the utterance that were called as a source of discourse but also it can be seen from the intonation and gesture language.

The subject of the data was taken from online news in detik finance which report of salt import. That site accessed from the site of https://m.detik.com which published on September 2018 by the headlines Punya Garis Pantai Terpanjang di Dunia, Kok RI Impor Garam? For the main data the researcher used all the text in that news including the headline. The data will be classified into each sentence category either it's passive or active. For analysing the data the researcher would focus on the structure utterance and the word use. The instrument of this analysis is the researcher itself and for this study the researcher used the available data.

This study use qualitative approach as the design which use news as document study. The researcher use this approach because it can describe systematically and also the characteristic of data. The qualitative approach try to describe clearly about the people, object, event, places, conversation, and other. This study also used discourse analysis as the method which concern in discourse power in society. The text also analysed by using lexical classification by Halliday's Systemic Functional Grammar through the news which refer to its headlines as the paradigm. Through the news the writer will select the utterances or the sentence in each form for revealing the social context.

\section{RESULT AND DISCUSSION}

After analysing the text the researcher get some finding which has classified into some categories. For the first problem the researcher would find the functional of using lexical choice which has effect to the headline in revealing the ideology of the news, for that case the finding of the first question would describe below. For the first step the object is a discourse which contain about the clauses. To find the meaning the researcher would analyse the sentence with lexical pattern which would come up the meaning. For that purpose the researcher begin from lexical meaning which focus on denotative and connotative meaning.

\section{Lexical pattern}

The word which used for composing the discourse are the selected word that has the power hidden and it controlled by the journalist or the media that launched the news. 
For this section in lexical pattern there are two component used for the analysis, lexical meaning and lexical structure.

\section{Lexical meaning}

In this focus the analysis would concern in denotative and connotative meaning of the clause. While, as the Karaf, 2009 which cited in Kusumawati, 2011 denotative meaning such as word or the combination of word or may be clause that has the directly and objectively meaning as it is without any interpretation. Directly, the researcher found that almost the text use denotative meaning in sentence, imagine the purpose of the news is report the real condition of the topic. In example the sentence:

\footnotetext{
Indonesia adalah Negara kepulauan dengan garis pantai terpanjang di dunia mencapai $99.093 \mathrm{~km}$. dengan garis pantai sepanjangitu, kok RI masih impor garam?

Menteri Perdagangan Enggartiasto Lukita blak-blakan soal alasan Indonesia masih impor garam meskipun punya garis pantai terpanjang di dunia.

Menurut Enggar, ada 2 faktor utama yang menyebabkan produksi garam Indonesia tak maтрu memenuhi kebutuhan nasional sehingga mengharuskan pemerintah melakukan impor.

Pertama adalah iklim atau cuaca di Indonesia yang dianggap kurang mendukung untuk memproduksi garam.

Kondisi ini jauh berbeda dengan wilayah di belahan bumi lain seperti Darwin yang hanya hujan satu bulan dalam setahun.

Factor lainnya adalah kualitas air laut alias tingkat kemurnian air laut yang menjadi bahan baku utama dalam memproduksi garam.
}

It known that all the sentences use the denotative word that has the originally meaning as it meaning. Based on the example of the data above, the media wants to show that there was a pro opinion that Indonesia was proper to do the salt import. Which shown that the writer of the news made an opinion to the reader that salt import is not a big problem, the statement from the minister of trade appears to strengthen the opinion of the news writer.

Another text that has the opposite in lexical pattern in meaning looked from the connotative meaning in sentence. Connotative could be referred into something positive or negative. Connotative also the meaning of word that use implicitly it refers to the cultural aspect that represent as a word. While the writer use connotation meaning there was a power of discourse that hidden behind the clause to make an abstract concept to the reader. To support the definition of connotative here the example of the clause as below.

Meski demikian, bukan berarti Indonesia bakal selamanya menjadi budak import garam. Ada cara lain yang bisa dilakukan untuk meningkatkan produksi garam nasional, salah satunya adalah menetapkan lokasi yang tepat untuk dijadikan sentra produksi garam.

"mana mungkin (menghasilkan garam berkualitas), coba lihat lautnya saja cokelat," jelas pria 66 tahun ini.

From the sentence above the clause refers to the negative meaning in connotative. The clause menjadi budak import garam it does not mean as the fact of the clause, the word "Budak" according to Wikipedia it such as condition while someone has controlled with another. It use for describing the purpose of labourer, worker or trade. From sentence above the clause said, bukan berarti Indonesia bakal selamanya menjadi budak import garam it implicitly whether Indonesia being the important of salt but it just temporary and not be permanent. That clause serve that actually the country such as Indonesia which has the longest coastline in the world it is not properly to do salt import. 
For that reason known that all the sentences which use for declaring the news much of them use denotative word to explain how the real condition happened. Since this topic become blooming in the middle of 2018 , there was many pro and contra response that appears from the public or the government itself.

Another definition the last sentence that said coba lihat, lautnya saja cokelat, the word cokelat when we translate in English as a brown is the word that describe the colour. While in the real life we see that the ocean directly blue or green. It use connotative that brown for the water colour has negative perspective, that the water must be murky and dirty caused of the waste and much of rubbish which pollute the ocean. That word implies that something negative happen that make the main problem in producing salt in our selfcountry.

From that purpose of using the lexical meaning, denotative and connotative has it function among sentences and clause. While choosing the correct word would be the primary action to avoid the clause from the wrong interpretation to the reader. Absolutely the writer of the news has selected the word to make impression of topic while reader get the information from the news.

\section{Lexical Structure}

Another way to analyse the data the researcher come to the structure that use in the whole of the text. There are some component in lexical choice which applied as the word structure, such as hyponym, polysemy, homonym, antonym, and ambiguity. For the finding the researcher found that much homonym use in the whole of the text and several of synonym and ambiguity supported. As the function homonym is the word classification which has different meaning in same word. For the example the sentence..

"kita (indonesia) iklim kita, di jawa ini hujan itu 4 sampai 5 bulan dalam setahun," ujar Enggar dalam blak-blakan di kantor detikcom, Jakarta, Kamis

The word "bulan" identified as the homonym, factually the word "bulan" is the one of satellite which surrounded the sun for another meaning the word "bulan" is the month which has twelve kinds in a years. As the context it describe as a month or duration of rainy which has a big impact in producing the salt.

Another lexical structure the found in this text is homonym. Synonym is words classification which describe the word in the same meaning in the different letter. The author use homonym to make the statement clear or to make an emphasis on the statement. For the evidence the text which use the synonym exposed as

"Pertama adalah iklim atau_cuaca di Indonesia yang dianggap kurang mendukung untuk memproduksi garam".

Menurut Enggar, ada 2 faktor utama yang menyebabkan produksi garam Indonesia tak mampu memenuhi kebutuhan nasional sehingga mengharuskan pemerintah melakukan impor.

The words which underlined has synonym purpose which describe in same purpose. For the first sentence known that the diction "cuaca" and "iklim" have same meaning, while it present differently letter. It also same with the last sentence that use diction "faktor" and "sebab" it also same meaning in different presentation. Synonym used to avoid repetition word or text, than the author us synonym in repetition the purpose in different diction.

The next lexical utterance that appears around the text is ambiguity. As its function ambiguity define as the clause that has same purpose. The researcher found there are four clauses that defined as ambiguity. Here some example of ambiguity. 
"Mana mungkin (menghasilkan garam berkualitas), coba lihat lautnya saja cokelat," jelas pria 66 tahun ini.

Meski demikian, bukan berarti Indonesia bakal selamanya menjadi budak impor garam. ada cara lain yang bisa dilakukan untuk meningkatkan produksi garam nasional, salah satunya adalah menetapkan lokasi yang tepat untuk dijadikan sentra produksi garam.

Kondisi ini jauh berbeda dengan wilayah di belahan bumi lain seperti Darwin yang hanya hujan satu bulan dalam setahun.

From those sentences above, the clauses which underlined has the purpose of ambiguity. We see for the first sentence the clause sounds "coba lihat lautnya saja cokelat" it has more than one meaning, absolutely this clause does not mean as it is, but it combine as the water which coloured brown detected as that water has polluted by trash or waste. It also can be called as connotative meaning. Another example which has definition as ambiguity in next sentence which has clause "indonesia bakal selamanya menjadi budak impor garam" this clause has two meaning first, Indonesia as a real being the slave which has a skipper or Indonesia be an receiver for importing salt. However, the sentence refers to the second meaning that Indonesia would be a receiver temporary. For those example, the author wants to report that the condition of Indonesia is very poor in importing salt, it caused much of rainy in side of the location which believe can be a central of salt production.

\section{Linguistic Function}

To combine the term in linguistic which has an ideology the clause not only seen from the grammatical rule but it also need word choice, sentence order and sentence form in the utterances (Fowler cited in Kusumawati, 2011). The utterances combine to express the opinion of the author and justify the condition as it own. As known from the linguistic perspective in CDA, language does not able to be neutral as long it consist of an ideology. Functionally, linguistic as a general has it role through language. Refers to the Halliday in ideational metafunction, he divided into two category it logical and experiential. Both of that terms refers to the grammatical source that build the unit of grammatical into complex unit which combine the clauses. For this function, the analyses would come to the transitivity clause system.

This system defined as a grammar unit systematically used exposing the relation between participants which involved the situation of communication, action, or condition that happened (Halliday via Fowler, 1986) which cited in Kusumuwati, 2011. For that definition transitivity divided into two categories there are transitive and intransitive. Transitivity consist of the analysis process types, participant types, circumstance types. Another pattern that support the analysis seem from the clause in nominalization and passivization. For the first example, the researcher would take the first sentence as mind topic of the news, the example as the sentence below;

Lakarta- Indonesia adalah Negara kepulauan dengan panjang garis pantai terpanjang di dunia mencapai $99.093 \mathrm{~km}$. dengan garis pantai sepanjang itu, kok RI masih impor garam?

For the first sentence which underlined the researcher claim that only process of transitivity that available in that statement. It describe the event or the knowledge of the object or the participant. It describe clearly as the mind topic which introduce the point of the problem. From the first sentence we cannot claim that it included as transitive or intransitive because through the sentence define as noun clause. We carry on to the second text;

Menteri perdagangan Enggartiasto Lukita blak-blakan soal alasan Indonesia masih impor garam meskipun punya garis pantai terpanjang di dunia. 
From this sentence known that as the transitivity system it found that sentence have it process as the word "blak-blakan" that has the same meaning with saying. It also has the participant of the event as "Menteri perdagangan Enggartiasto Lukita" and it completed with the circumstances in clause "soal alasan Indonesia masih impor garam meskipun punya garis pantai terpanjang di dunia" as the complement. Seem for the process transitivity, the sentence included in transitive type because the verb of the sentence followed by the object that describe the complete event.

Switching from the transitivity pattern, the researcher found that the whole news has nominal sentences. Nominal sentence is a verb or adjective as a noun, continually this nominal sentence act as a heading of the phrase or a sentence. This definition can be proven in the example text below;

Menurut Enggar, ada 2 faktor utama yang menyebabkan produksi garam Indonesia tak mampu memenuhi kebutuhan nasional sehingga mengharuskan pemerintah melakukan impor.

We can see from the underlined phrase as a heading of the problem in that sentence. It proven from the word "kebutuhan nasional" which that phrase combine from the verb "butuh", from that describing the phrase "kebutuhan nasional" refers to the "garam" or salt which can be primary object in this topic.

Another classification which refers to the structure context is in passivization. This process need changing an active voice into passive voice, this process need to make the focus of the object as the mind sentence. This pattern use for changing the listeners focus of the sentence and change the meaning and perception of reader/listeners. It can be proven as the example data below;

"Jadi memang areal ( pertambakan garam) itu tidak ditentukan panjang garis pantai. Tapi apakah mungkin atau tidak (menjadi sentra produksi garam)? di situ dilihat dari iklim," tutur dia.

Meski demikian, bukan berarti Indonesia bakal selamanya menjadi budak impor garam. ada cara lain yang bisa dilakukan untuk meningkatkan produksi garam nasional, salah satunya adalah menetapkan lokasi yang tepat untuk dijadikan sentra produksi garam.

For the example above, the phrase which underlined are passive sentence, while the object primary being the focus. For the next sentence we can see that there are two voice in a sentence, while the beginning sentence used positive voice and change into passive voice for the next. The sentence changes to make the reader change their focus about the topic. It prove from the object of the text which become a heading of the text.

Known as the finding of the data shown that there are some transitive pattern appear that use for declare the object clearly. This way used to show the purpose of the media in combining the discourse of the topic. Another pattern of clause that use for the news is in passive-active voice and nominalization. To the whole of the sentence normally to use active and passive voice, it use for changing the focus of the reader or the listener in their perspective. For this case, the ideology can appear slowly from each pattern of clause that use in the whole of news. When it chain to its headline which says Punya garis pantai terpanjang di dunia, kok RI impor garam? it known that there are two clauses in a sentence the one is affirmative clause and another is interrogative sentence use for the headline news. Affirmative sentence use for introducing knowledge of the problem and the next clause is interrogative clause to declare the gap or the problem that happened.

To reveal the ideology of the headlines news we know that the headline consist of two clauses as mention before. The last clause refer to the question that ask for the feeling curious about the tragedy, it shown from the word "kok" to express the condition. According to KBBI dictionary it explain into some meaning, first meaning explain as a ball 
that used for playing badminton, second meaning explain as a word to emphasize or reinforce the aim and the last meaning explain as a word which used to ask in "Why" situation. From that explanation, the word "kok" in the headline use for asking question why it can happen. It express the curious feeling because it supported with the clause before which says Punya garis pantai terpanjang di dunia, this statement declare that the general condition of the country which impossible happened.

From that discussion seem that the media shows the contradictive of the case in the headline, even the government try to wrap up that case such as something looks natural. When we look through the sentences in the news the media or the author shows all the statement which refer to the government that pro about the situation. Moreover, the media try to show about contradiction that look like unnatural things, with the word "terpanjang di dunia" that used in the first clause of the headline it contain the ideology that factually our country, Indonesia has a power to prevent the import of salt. Furthermore, the media show all of direct statement from the government to set the mind of the reader think that the situation was natural which supported by some geographically reason.

Known that language never be neutral if it still has an ideology and media take a role in the formatting of an ideology through language structure that used. For the discussion known that the headline reveal contra perspective which appear from interrogative clause, although not all the interrogative clause refers to the contra perspective. From the finding the researcher claim that the author or the media show that there is not any positive impression about the news case. However, the media show that it's such a neutral case depend on the powerful statement of Enggartiasto Lukita as trade minister of Indonesia.

It would be totally different with the other finding in the previous study that used to be primary references to this study. In the same way beyond this study and other references is we use Critical Discourse Analysis as the primary approach in revealing the ideology of the news context. However, some study did the comparing idea between a medium to another. Concern to this study the researcher found the ideology comes from peeling the headline which supported by the discourse through the news. As the finding the headline hide the different ideology with the context of news, it imaged from the direct statement which comes out of the media that show through the text.

\section{CONCLUSION}

Discourse is a part of language that has a power to control the mind of language receiver. While, news is the one of language that compose from the sentences that use the ideology behind its discourse. Every single use the headline as the introduction to come to the mind topic. Moreover, we as a reader are able to get our own perception begin from the headline news. After doing the analysis the researcher conclude that news which has the headline Punya garis pantai terpanjang di dunia, kok RI impor garam? Consist of two clauses are affirmative as the statement and the last is interrogative clause as a question. However, the headline show contra perspective which known from the interrogative clause that use in the last clause from the headline. Revealing the ideology of the headline the researcher have the general statement that media shown the different perpective between the minister. From that analysis the researcher claim that media or news doesn't show fully contradictive perspective it proved from all the direct statement of Indonesian trade minister which shown that the case as the neutral case in our country. 


\section{REFERENCES}

Fairclough, N. (1995). Critical discourse analysis: the critical study of language. New York: Longman.

Fowler, R. (1986). Linguistic critism. New York: Oxford University Press.

$\mathrm{He}, \mathrm{X}$. (2015). Contrastive analysis of lexical choice and idiology in news reporting the same accidents between Chinese and American Newpaper. DOI, 2356-2365.

Isti'anah, A. (2018). Rohingya in media: critical discourse anlysis of Myanmar and Bangladesh newspaper headlines. Academia. edu, 18-23.

K, A. \&. (2010). A study of 'Kenry' in Japanese and 'Hak' in Indonesian. Jurnal Humaniora, $22,22-30$.

Karaf, G. (2009). Diksi dan gaya bahasa. Jakarta: PT Gramedia Pustaka Umum.

Kusumawati, A. J. (2011). A discourse analysis of SBY's International speech text: a study on critical linguistic. Journal of English and Education, 1-28.

Matthiessen, M. H. (2004). An introduction to functional grammar. London: Arnold.

Metilia, R. A. (2013). A discourse analysis of news headlines: diverse framing for a hostagetaking event. Asian Journal of Social Sience an Humnity, 71-78.

Prasetyani, N. Y. (n.d.). Translation analysis on idiology lexicon choice in how to win friends and influence people book and its Indonesia translation. International Seminar Prasasti III, 568-573.

Reid, A. (2008). Menuju sejarah Sumatra: antara Indonesia dan dunia. Jakarta: Yayasan Obor.

Santosa, R. (n.d.). Critical discourse analysis: systemic functional linguistic. International Seminar Prasasti III, 46-57.

Xianzhoung He, X. Z. (2015). Contrastive analysis of lexical choice and idiologies in ews reporting the same accidents between Chinese and American newspaper. Theory and Practice in Language Studies, 2356-2365.

Yanto, E. M. (n.d.). The strategy in newspaper text (a critical discourse analysis of newspaper text). International Seminar Prasasti III , 891-896.

Zacharek, S. (2008). The New York Times. Retrieved February 12, 2013, from The New York Times: http://www.nytimes.com/2008/04/27/books/review/Zachareck

\section{Appendix}

Posted by Detik.com

Jumat, 14 sep 2018 15:56

Selfie Miftahul Jannah - Detik Finance

Punya garis pantai terpanjang di dunia, kok RI impor garam?

Jakarta- Indonesia adalah Negara kepulauan dengan panjang garis pantai terpanjang di dunia mencapai $99.093 \mathrm{~km}$. dengan garis pantai sepanjang itu, kok RI masih impor garam?

Menteri perdagangan Enggartiasto Lukita blak-blakan soal alasan Indonesia masih impor garam meskipun punya garis pantai terpanjang di dunia. 
Menurut Enggar, ada 2 faktor utama yang menyebabkan produksi garam Indonesia tak mampu memenuhi kebutuhan nasional sehingga mengharuskan pemerintah melakukan impor.

Pertama adalah iklim atau cuaca di Indonesia yang dianggap kurang mendukung untuk memproduksi garam.

"kita (indonesia) iklim kita, di jawa ini hujan itu 4 sampai 5 bulan dalam setahun," ujar Enggar dalam blak-blakan di kantor detikcom, Jakarta, Kamis

Kondisi ini jauh berbeda dengan wilayah di belahan bumi lain seperti Darwin yang hanya hujan satu bulan dalam setahun.

Factor lainnya adalah kualitas air laut alias tingkat kemurnian air laut yang menjadi bahan baku utama untuk memproduksi garam.

Wilayah sentra produksi garam seperti Cirebon misalnya, kualitas garamnya kurang maksimal lantaran kualitas air lautnya yang kotor karena sudah banyak tercemar.

"mana mungkin (menghasilkan garam berkualitas), coba lihat lautnya saja cokelat," jelas pria 66 tahun ini.

Sehingga menurutnya, panjang garis pantai tak bisa jadi patokan RI bisa menjadi produsen garam terbesar di dunia.

"Jadi memang areal( pertambakan garam) itu tidak ditentukan panjang garis pantai. Tapi apakah mungkin atau tidak (menjadi sentra produksi garam)? di situ dilihat dari iklim," tutur dia.

Meski demikian, bukan berarti Indonesia bakal selamanya menjadi budak impor garam. ada cara lain yang bisa dilakukan untuk meningkatkan produksi garam nasional, salah satunya adalah menetapkan lokasi yang tepat untuk dijadikan sentra produksi garam.

Salah satu wilayah yang paling mungkin jadi sentra produksi garam adalah Nusa Tenggara Timur.

"yang paling efektif dan yang paling memungkinkan adalah dari NTT," jelas Enggar.

NTT memiliki dua factor utama yang paling memungkingkan untuk menjadi sentra produksi garam nasional. Pertama adalah iklim cuaca.

"di Timor, satu tahun dua bulan setengan hujan. Kemudian d Flores satu tahun 3 bulan hujan" jelas dia.

Sementara kualitas air di sana juga terpantau cenderung lebih jernih ketimbang daerah lain di Indonesia.

“di NTT itu adalah yang terbaik," sambung dia.

"itulah pemerintah pusat dan gubernur NTT yang baru ini melakukan berbagai cara untuk, mebuat NTT sebagai produsen garam," tandas Enggar. 